\title{
Significance of Business Philosophy towards The Covid-19 Post Pandemic
}

\author{
Lukman S. Thahir ${ }^{1}$ \\ \{lukmansthahir@iainpalu.ac.id $\left.{ }^{1}\right\}$ \\ Faculty of Islamic Creed, Civilization and Propagation, State Institute for Islamic Studies (IAIN) Palu \\ Central Sulawesi, Indonesia ${ }^{1}$
}

\begin{abstract}
This article aims to explore strategic perspectives and philosophical phases to respond business problems mostly affected by the Covid-19. The research questions are focused on two issues: 1. What is Business Philosophy? and 2. How is the significance of business philosophy towards the post-Covid-19 pandemic? To answer this questions, the study employs social humanities approach by focusing on descriptive-analytical and philosophical methods. The results obtained are two-fold: First, in handling problems due to the Covid-19, business philosophy as the driving force for navigating the company to achieve success, does not see the Covid-19 problems, especially the ways it handle the post Covid-19 pandemic, in only one dimension, but multi-dimensional. Second, for business practitioners, to handle Covid-19 problems should begin within themselves by altering their perspectives towards the Covid-19 problems where sense of threatening and damaging sides of the problems towards business development should be driven into challenges, opportunities and profitable opportunities through collectivecollaborative and humanist works.
\end{abstract}

Key Word: Philosophy, Business Philosophy, Pandemic, Covid-19, Post Covid-19

\section{Introduction}

What important lessons can we take after the New Corona Virus (SARS-CoV-2) swept the world within approximately 8 months? As commonly known, the outbreak of the virus began in December 2019. It emerged and triggered an epidemic striking against acute respiratory syndrome (COVID-19) in humans, which was centered in Wuhan, China [1]. Within only 5 months period, the virus has spread to more than 213 countries, with 24.537 .560 cases and 832.879 deaths, as of 29 August 2020 [2]. The explosion and escalation of the virus is so fast and deadly that not only the World Health Organization (WHO) declared it as a global pandemic, but it also shattered the foundations of the world economy, especially in business sector. Quoting reports from the World Economic Forum [3] and the International Labor Organization [4], that the COVID-19 crisis has affected communities and economies worldwide, and has resulted in crises and economic shocks, the impact of which is not only decreasing supplies (production of goods and services ) but also demands (consumption and investment). Production disruptions, which started only in Asia, have now spread to supply chains around the world. All businesses, regardless of size, face serious challenges, especially those in the aviation, tourism and hospitality industries, with real threat of significant declines in income, bankruptcy and job losses in certain sectors. Amid tremendous challenges and uncertainties, and countless personal tragedies, country leaders and C.E.O's various business 
firms are under pressure to make decisions in their attempts to manage the immediate impact of the pandemic and its consequences. For example, recent data from UNIDO's seasonally adjusted Industrial Production Index [5]. (April 2020 vs December 2019) show that lower and upper middle income countries have been significantly affected by the COVID-19.

Responding to this problem, there are at least three strategic steps that we can take to become a starting point for making solutions to the impact of the Covid-19. First, one of the few investments from the pandemic is that this period in history will have profound influence on our generation and how we live our lives in the future. In a few short weeks we've already had to rethink how we work, how we interact and even how we care for our families. Economic theorists have started to look at how this period may change our habits and our mindsets in the coming years [6]. Second, The pandemic Covid-19 shows that our health depends on the health of others and that the health of others depends on our health. The policies of physical distancing in turn show that our well-being depends on the well-being of others and that the well-being of others depends on our well-being. There are no individual solutions to this health, economic and social crisis; the solution must be collective [7]. Third, using social humanities and behavioral science to support the COVID-19 pandemic response. The COVID-19 pandemic represents a massive global health crisis. Here we discuss evidence from a selection of research topics relevant to pandemics, including work on navigating threats, social and cultural influences on behavior, science communication, moral decisionmaking, leadership, and stress and coping [8].

Of the three strategic steps presented above, this article will only review the third strategic step, namely using social humanities and behavioral science, with scientific emphasis on philosophy and business. Therefore, this paper aims to explore strategic perspectives and philosophical steps to respond to the problems most affected by the Covid-19, namely the business problem. Why is philosophy used to respond to business problems? Borrowing the language of Anders Paulsen [9]. Many business people fail, not because they do not have an entrepreneur mentality, not because they do not understand the principles of doing business, but because they fail to see the problem in different angles or various nuances. In the expression of Jerry Kirkpatrick [10]. Therefore, this research will focus on two main problems: 1. what is business philosophy? And what is the significance in addressing the Post Covid-19.

\section{Methods}

Essentially, this type of investigation is social and humanities research which is grounded on literature study. According to Soerjono Soekanto [11] social research is an in-depth examination of social facts which is aimed to seek a solution to problems that arise in the symptoms concerned. Meanwhile, according to the Big Indonesian Dictionary (KBBI) of the Ministry of Education and Culture, humanities are sciences that are aimed to make humans more humane, in the sense of making humans more cultured, [12] applying descriptiveanalytical and philosophical methods. The first one is meant to take a problem or to focus attention on the problem as it is, then processed and analyzed to draw conclusions. Meanwhile, the second is philosophical. It is a perspective or paradigm that aims to explain 
the essence or wisdom of something behind the object. In other words, a conscious effort is made to explain what is behind something that appears [13].

\section{Result and Discussion}

Important questions to start this section are: What is Business Philosophy? To answer this question, I'm not trying to explain it academically, it must be very complicated, and tedious. For these very reasons, many people are not interested in studying philosophy because they consider it as a subject that is difficult to understand. In a business context, philosophy is not really like that. Therefore, for the purpose of simplifying it, so that it could be easier for us to understand, especially in relation to business, I would like to state that philosophy is simply having a world view, "the way they see and understand the world", the way we see and understand the world. , or someone's point of view to interpret the world.

For more details, I would like to give an example by quoting my book Business Philosophy: Ways to Succeed in Building Your Business [14]. In this book, it is explained that "All successful people in this world must have a philosophy or world view, without exception. No one is successful, unless he certainly has a world view. This world view can come from anywhere, inspire someone, then he becomes the basis for thinking, acting and making decisions. That is what is meant by philosophy. Bill Gate, for example, the inventor of the "magic creature" coined the word Microsoft in 1975. He discovered that this Microsoft, with his friend Paul Allen, did not just appear. He drew inspiration from Dr. Henry Edward Roberts, an early personal computer developer, died Thursday in Georgia at the age of 68, after seeing an article about the MITS Altair 8800 on Popular Electronics. Some of his inspirational quotes are: "Don't compare yourself with anyone in this world ... if you do so, you are insulting yourself". He also once said: "Success is a worthless teacher. It seduces smart people into thinking they can't lose". Likewise Warren Buffett, he was not one of the most successful investors of all time alone. He has mentors, teachers and colleagues who help him develop a smart investing style over time. The likes of Benjamin Graham, David Dodd and Phil Fisher helped him develop the tools needed to build his $\$ 92.5$ billion business empire. Buffets' inspirational words that we can make our world view, include: "It takes 20 years to build a reputation and five minutes to ruin it."You can't make a good deal with a bad person.". "It's better to hang out with people better than you. Pick out associates whose behavior is better than yours and you'll drift in that direction. "

From this explanation, if it is related to business, it can be concluded that what is meant by business philosophy is a set of principles and beliefs that are owned by a company or every business actor [businessman] to move and navigate the company to achieve success. This navigation or world view serves as a blueprint for the operation of the entire business, which affects its vision-mission and objectives. A business philosophy might also list company values that are important to its founders, executives, and employees. The philosophy for the company reflects the values of its leaders, helping businesses to feel more personal and uphold collectivity. Business philosophy can also be understood as a motivational system or basic principles that serve as the basis for a company's beliefs or actions. Those involved in corporate management may wonder how this definition relates to success in the business world. Managers and company owners may be surprised to learn that a strong philosophy is 
the cornerstone of success in business. As you begin to understand and develop a philosophy for your business, it becomes easier to build a productive and cohesive organization that can handle any challenges that may arise. In this way, business philosophy is akin to a roadmap for a company. If you are visiting a new city, it can be frustrating trying to navigate without a GPS or map. You don't know how to get to various places or how long it takes to get there. This same analogy can be applied to a company without a solid business philosophy.

On the basis of the above thoughts, and to answer the two research problems, which are related to the significance of business philosophy in responding to the Covid-19 problem, I would like to recite Ander Poursen's [14] question: Why Do Future Business Leaders Need Philosophy? I deliberately raised this, to describe how philosophy plays a very important role in solving the various challenges and economic crises faced by business people in the postCovid-19 era. According to Poursen, after the financial crisis, an era of severe turbulence, there has been an increase in the rapid changes and complexity of life. Black clouds hang over the last decade's economic prosperity and global consumption habits, fundamentally challenging business objectives. Often the approaches to business practice are onedimensional, lacking richness and depth. This is true for both supporters and critics of current business practices. In these times, it is important to be able to see the world in many nuances. Citing Thomas Hurka, professor of philosophy at the University of Calgary and Payscale's latest research results, Poulsen not only raises the case of a philosophy graduate who, after being hired, progressed faster than their peers with only business degrees, but also Thomas Hurka, strongly recommends the younger generation to consider philosophical thinking, if they want to be successful in business.

This is supported by recent research by Pay scale, which shows that while philosophy graduate starting salaries may be lower than those for business degrees, mid-career, philosophy graduate salaries exceed those of marketing, communications, accounting, and business management. Taking this into account, it seems that having a proper business degree from a prestigious business school does not guarantee a successful career in business. Following this line of thinking, Matthew Stewart, former management consultant for the Mitchell Madison Group said, "If you want to be successful in business, don't get an MBA.

Study philosophy instead." In his experience, MBA programs basically involve, "taking two years of life and get you into debt, all for the sake of learning how to keep a straight face when using phrases like "thinking outside the box," "win-win situations," and "core competencies. "While this arguably exaggerates the current state of business education, it is hard to ignore the truth: the concept of 'business as usual' in management education is rapidly becoming obsolete, while global socio-economic challenges are only for the mature [adult] way of thinking. In many countries, labor market conditions are deteriorating with unemployment rates to unprecedented levels. For younger generation, job prospects are declining, as they are often the 'last in' and 'first out' of the labor market. Nowadays, it's a common joke that the phrase most philosophy graduates use is "Would you like French fries and a Coke? It's a joke in the West to explain that philosophy graduates find it difficult to find jobs. But is this an actual representation of the real world? Surprisingly, a study conducted by CNN showed that only $5 \%$ of people who recently earned their philosophy diploma had problems finding a job. In addition, many well-known entrepreneurs such as Reid Hoffman, Peter Thiel and Carly Fiorina attribute their overall success to their education in philosophy. 
How does philosophy respond to global economic shocks and crises, especially business problems due to Covid-19? In my book Philosophy of Pandemic: Response to Religious Social Problems in the Covid-19 Period [15], it is described very long and clearly. In this article, I will briefly state that starting from human fears due to the impact of the Wuhan phenomenon. This phenomenon even though it had not spread throughout the world at that time, had psychologically affected the feelings of all mankind, affected the tissue cells in their brains, and then alarmed the body of the danger and threat of death, then what happened was anxiety, fear and panic.

For example, the Covid-19 can really make people panic, but a proactive person is not affected by the situation, on the contrary he with his free will or his own choice responds in a positive way, that this condition is God's way of training himself to be a strong person and understand suffering and appreciate how this life is very important and meaningful. With the Covid-19, we are taught to come back to ourselves. It turns out that the remote control in our life is not in other people or social media, but within ourselves. Never let your thoughts, views, or news on social media regarding the Covid-19 influence your perception. Eleanor Rosevelt once expressed her view, "No one can hurt you without your consent". Or Gandhi's words, "they cannot take our pride, if we don't give it to them". Since the remote control of your life is in your own hands, decide positively what you will think. The seeds you sow will produce similar yields. Socrates said, if you plant apple seeds, you will get apples. Likewise with the mind, if you cultivate negative thoughts, the results you get will be negative results. If you plant the seeds of love, pleasure and happiness, then the results you get will be the same as the seeds you plant [15].

How to reflect this awareness in today's concrete situations, especially in the post-Covid19 period, I want to discuss this issue by looking at the answers of Amie Thomasson, philosophy professor, Dartmouth University, when she was asked about the anxiety and alienation of society due to the Covid-19. She answered as following [16] :

"It's no surprise that so many people are feeling bad through the isolation - not just worried for themselves or their loved ones, but more deeply, feeling a kind of meaninglessness. Heidegger talked about two sorts of things that are distinctive of our being human, and that give our lives the only kind of meaning we can hope for: One is our projects - the things we care about, work toward, are engaged in - and the other is our being with others. The pandemic, and the isolation it has brought, has cut most of us off from our projects - whether it's baking cakes for weddings, teaching first-graders or cheering on the Rays. And it's cut us off from much of our normal ways of being with other people. Once we get disengaged, there's also the threat that the things we once cared so much about no longer seem important. And that can bring on the feeling that it's not just a temporary state - it's not just that life feels meaningless now, while we're stuck inside, but maybe it was never meaningful to"

The same is expressed by Kevin Scharp, philosophy department, University of St. Andrews, Scotland [17]. He Said:

"This is not an existential crisis in the sense of Homo sapiens going extinct. That is not going to happen. Even the direst predictions estimate no more than 5 percent of 
the population will be dead. Nevertheless, it is also worth emphasizing that many things about our identities will change, and these could be thought of as existential changes. I'm thinking about personal identities ("I'm a world traveler") and societal identities ("We're a tourist destination"). In a sense, the COVID-19 has forced every person on earth and every society and humanity itself to go through a transformative experience. That means we get to make up new identities for ourselves to some extent. Let's go with "we are environmentally responsible," and "we care about everyone's rights and quality of life."

The views of these two philosophers in responding to the Covid-19 show their ability to cultivate critical and innovative thinking systems, which Makunda Raghavan [17] calls one of the most important skills gained from studying philosophy. The former is something that most people expect from learning philosophy but not the latter. Studying philosophy requires you to reason through your assumptions and the ideas of others, finding the problems in both and also finding a solution. This is the key point of Philosophy: the idea of finding problems and solutions for those problems, some of these problems are theoretical and other problems are practical and real. This is what innovation requires, the finding of a problem that exists in the world and also finding or creating a solution. Weber Shandwick [6] said that" One of the few inevitabilities from the pandemic is that this period in history will have profound influence on our generation and how we live our lives in the future.

\section{Conclusion}

In the 21 st century, the discourse on health and disease is no longer the monopoly of medicine, because there are other factors outside of clinical reality that influence that matters, especially socio-cultural factors. Many philosophers, biology, anthropology, sociology, medicine, and other fields of science have tried to provide a better understanding of the concept of health and illness in terms of their respective disciplines. The problem of health and illness is a process related to the ability or inability of humans to adapt to the environment both biologically, psychologically and socio-culturally. This paradigm of thinking also applies in the field of economics, especially in business. Business people, cannot see business practices as one-dimensional, but must be multi-dimensional, especially those related to business philosophy as the driving force for navigating the company to success. This navigation or world view serves as a blueprint for the operation of the entire business, which affects its vision-mission and objectives.

\section{References}

[1] Y. R. Guo, Q. D. Cao, Z. S. Hong, Y. Y. Tan, S. D. Chen, H. J. Jin, et al., "The origin, transmission and clinical therapies on coronavirus disease 2019 (COVID-19) outbreak - an update on the status," Mil Med Res, vol. 7, p. 11, Mar 132020.

[2] World-Health-Organization. WHO Coronavirus Disease (Covid 19) Dashboard [Online]. Available:

https://covid19. who.int/?gclid=Cj0KCQjwqfz6BRD8ARIsAIXQCf0WzdiKbHtQuZTtxaU919RYc zCRsR80nHL3-iQ1U6vxKpebW3yyMOkaAsvaEALw_wcB 
[3] World-Economic-Forum. Challenges and Opportunities in the Post-COVID-19 World [Online]. Available: https://www.weforum.org/reports/post-covid-19-challenges-and-opportunities

[4] International-Labour-Organization. COVID-19 and the world of work: Impact and policy responses [Online]. Available: https://www.ilo.org/global/topics/coronavirus/impacts-andresponses/lang--en/index.htm

[5] United-Nations-Industrial-Development-Organization. Coronavirus: the economic impact [Online]. Available: https://www.unido.org/stories/coronavirus-economic-impact-10-july-2020

[6] Weber-Shandwick. The New Normal? The Future After COVID-19 [Online]. Available: http://webershandwick.scot/the-new-normal/

[7] The-Organization-of-American-States. Post-Covid 19: OAS Portal for Consultations, Forum, and Repository [Online]. Available: https://www.oas.org/ext/en/main/covid-19/home

[8] D. Matthews. German humanities scholars enlisted to end coronavirus lockdown [Online]. Available: https://www.timeshighereducation.com/news/german-humanities-scholars-enlisted-endcoronavirus-lockdown

[9] J. J. V. Bavel, K. Baicker, P. S. Boggio, V. Capraro, A. Cichocka, M. Cikara, et al., "Using social and behavioural science to support COVID-19 pandemic response," Nature Human Behaviour, vol. 4, pp. 460-471, 2020/05/01 2020.

[10] J. Kirkpatrick. The Importance of Philosophy to a Successful Business Career [Online]. Available: https://jerrykirkpatrick.blogspot.com/2009/08/importance-of-philosophy-to-successful.html

[11] S. Soekanto, Sosiologi Suatu Pengantar. Jakarta: Rajawali Press, 1986.

[12] KBBI. Kamus Besar Bahasa Indonesia [Online]. Available: https://kbbi.kemdikbud.go.id/

[13] S. Loeb, P. Morris, S. Dynarski, S. Reardon, D. McFarland, and S. Reber, "Descriptive Analysis in Education: A Guide for Researchers," Institute of Education Sciences, Washington DC2017.

[14] L. Tahir, Filsafat Bisnis: Kiat Sukses Membangun Bisnis Anda. Yogyakarta: Anwarul Quran, 2020.

[15] L. Tahir, Filsafat Pandemi: Merespon Masalah Sosial Keagamaan di Masa Covid 19. Yogyakarta: Pesantren Anwarul Qur'an, 2020.

[16] L. DeGregory. A philosopher's guide to the coronavirus [Online]. Available: https://www.tampabay.com/news/health/2020/04/10/a-philosophers-guide-to-the-coronavirus/

[17] M. Raghavan. Philosophy in Business: Is it relevant? [Online]. Available: https://www.linkedin.com/pulse/philosophy-business-relevant-mukunda-raghavan 